\title{
Storage of markies cultivar potatoes for prossessing ${ }^{1}$
}

\author{
Kharen Priscilla de Oliveira Salomão Petrucci $i^{2}$, Ariana Mota Pereira ${ }^{2} * \mathbb{D}$, Marialva Alvarenga Moreira ${ }^{2}$, \\ Paulo Roberto Cecon ${ }^{3}$,Fernando Luiz Finger ${ }^{2}$
}

$10.1590 / 0034-737 X 202168020001$

\begin{abstract}
The refrigerated induce the sweetening of the potato, which results in the dark color. The objective of this study was to determine the temperature and shelf life of Markies potato tubers under refrigerated storage for the processing of French fries. The levels of total soluble sugar (TSS), reducing sugars (RS), peroxidase (POD) and polyphenoloxidase (PPO) activity, color after frying and start of sprout were determined. The accumulation of TSS started at 30 days in the tubers at 4 and $5{ }^{\circ} \mathrm{C}$ and in the tubers at 6 and $8{ }^{\circ} \mathrm{C}$, at 150 days. The activity of POD and PPO were not influenced by temperature or storage time. Tubers at 4 e $5{ }^{\circ} \mathrm{C}$ showed higher TSS and RS contents and darker color after frying than tubers stored at 6 and $8{ }^{\circ} \mathrm{C}$ which had their color maintained within the industry-acceptable standard up to 240 days of storage. Temperatures of 4 and $5{ }^{\circ} \mathrm{C}$ delayed the onset of sprouting, starting at 150 days, and at temperatures of 6 and $8{ }^{\circ} \mathrm{C}$, the onset of sprouting occurred from 90 and 60 days of storage, respectively. It is concluded that the cultivar Markies should be stored at $6{ }^{\circ} \mathrm{C}$ for 240 days.
\end{abstract}

Keywords: Maillard reaction; reducing sugars; sprouting.

\section{INTRODUCTION}

The growing demand for fast-food products has increased the consumption of processed potatoes, requiring the expansion of industrial processing (Pereira \& Suinaga, 2015).

Markies cultivar occupies a prominent place in the crops because it presents greater resistance to reburn and double culinary aptitude (Ribeiro et al., 2012). It is a promising cultivar to serve the processed potato market because it presents low soluble sugar content, high starch levels, good post-fry color and pleasant taste (Thompson \& Morgan, 2015).

Regarding the constant supply of raw material for the industry, it is necessary the refrigerated storage of the tubers, in which, the determination of the ideal temperature is fundamental to maintain the quality, the physiological conditions of the tubers and the reduction in the sprouting (Khanal \& Yprety, 2014).
Storage at temperatures below $8{ }^{\circ} \mathrm{C}$ induce the accumulation of reducing sugars that make tubers unfit for frying. During frying, glucose and fructose react with the amino acids in a non-enzymatic reaction, named Maillard reaction, resulting in a product of poor quality and commercial acceptance, bitter taste and dark color (Chapper et al., 2004; Knowles et al., 2009).

Pre-fried potatoes are susceptible to enzymatic darkening as a result of the reactions catalyzed by the activity of polyphenoloxidase (POP) and peroxidase (POD) enzymes. These reactions occur during the peeling, cutting and slicing stages due to the breakdown of the cellular structures, allowing the contact between the enzyme and the substrate (Araújo, 2008). Because of the increasing demand for processed products and the influence of storage temperature on the darkening of pre-fried potatoes and after frying, it is necessary to understand the behavior of the Markies cultivar over refrigerated storage for its industrial purpose.

\footnotetext{
Submitted on November $6^{\text {th }}, 2019$ and accepted on October $30^{\text {th }}, 2020$.

'This work is part of the first author's Doctoral Dissertation.

2Universidade Federal de Viçosa, Departamento de Fitotecnia, Viçosa, Minas Gerais, Brazil. kharensalomao@yahoo.com.br; ariana.mota@ufv.br; marialvamoreira@yahoo.com.br; ffinger@ufv.br

${ }^{3}$ Universidade Federal de Viçosa, Departamento de Estatística, Viçosa, Minas Gerais, Brazil. cecon@ufv.br

*Corresponding author: ariana.mota@ufv.br
} 
The objective of this study was to determine the temperature and shelf life of Markies potato tubers under refrigerated storage for the processing of French fries.

\section{MATERIALAND METHODS}

Tubers of Markies cultivar potato (Solanum tuberosum L.) were produced in the region of Perdizes, state of Minas Gerais. Harvest was carried out 10 days after the complete drying of the aerial part of the plant, in November 2015. After the harvest, the tubers were selected and sent to the Laboratory of Post-Harvest of the Department of Plant Science of the Universidade Federal de Viçosa in Minas Gerais.

Curing was performed at $14{ }^{\circ} \mathrm{C}$ for 7 days. The temperature was reduced daily by $1{ }^{\circ} \mathrm{C}$ until reaching storage temperatures. The tubers were conditioned at 4 , 5,6 and $8{ }^{\circ} \mathrm{C}(\mathrm{RH} 90 \pm 2 \%)$ in the absence of light.

The analyzes of total soluble sugars (TSS), reducing sugars (RS), non-reducing sugars (NRS) peroxidase (POD) and polyphenoloxidase (PPO) activity and sprouting onset were carried out each 30 days, during 240 days of storage. Post-frying color were carried out before storage and during 240 days.

Sprouting onset was determined from the visualization of sprouted tubers.

Total soluble sugars and reducing sugars were extracted by using $5 \mathrm{~g}$ of tuber fresh mass. Then, $80 \%$ ethanol was added at $100{ }^{\circ} \mathrm{C}$, triturated and centrifuged three times for 10 minutes at $1500 \mathrm{~g}$. At each centrifugation, the samples were filtered and the combined final volume of the filtrates was standardized (Dubois et al., 1956).

Total soluble sugars were quantified by the Phenolsulfuric method (Dubois et al., 1956), using 1\% sucrose to make the standard curve. The reaction was composed of $250 \mu \mathrm{L}$ of the extract, $250 \mu \mathrm{L}$ of $5 \%$ phenol and $1.25 \mathrm{~mL}$ of sulfuric acid. Subsequently, the reaction was placed in a thermostatic bath for 20 minutes (min) at $30^{\circ} \mathrm{C}$. Reading was performed in a spectrophotometer (Genesys- 10UV, scanning, Germany) at $490 \bullet \mathrm{m}$, expressed in \%.

Reducing sugars were determined by the dinitrosalicylic acid (DNS) methodology described by Gonçalves et al. (2010) with adaptations. It was used $0.2 \%$ fructose to make the curve. For the preparation of $500 \mathrm{~mL}$ of DNS, it was used $5 \mathrm{~g}$ of dinitrosalicylic acid dissolved in $250 \mathrm{~mL}$ of distilled water at $80^{\circ} \mathrm{C}, 100 \mathrm{~mL}$ of $2 \mathrm{~N} \mathrm{NaOH}$ and $150 \mathrm{~g}$ of sodium and potassium tartrate $\left(\mathrm{KNaC}_{4} \mathrm{H}_{4} \mathrm{O}_{6} \cdot 4 \mathrm{H}_{2} \mathrm{O}\right)$. The reaction was composed of $500 \mathrm{iL}$ of DNS and $500 \mu \mathrm{L}$ of the sample, subsequently placed in water at $100{ }^{\circ} \mathrm{C}$ and after 5 min, $4 \mathrm{~mL}$ of distilled water was added in it. The readings were performed in spectrophotometer (Genesys- 10UV, scanning) at $540 \bullet \mathrm{m}$ and expressed in percentage.

Non-reducing sugars were calculated by the difference between TSS and RS and expressed in percentage.
To evaluate the post-fry color, the tubers were cut into sticks using a manual cutter and fried in electric fryer, with capacity for $3 \mathrm{~L}$ (Model: Ford ${ }^{\circledR}$ ) for $3 \mathrm{~min}$ at $180{ }^{\circ} \mathrm{C}$. The color of the post-fry potatoes was visually determined based on the grading scale recommended by the 'United States Standards for Grades of Frozen French Fried Potatoes' (USDA, 1967).

Enzymatic extracts of POD, PPO and proteins were obtained from $5 \mathrm{~g}$ of plant material and $15 \mathrm{~mL}$ of extraction buffer ( $0.1 \mathrm{M}$ potassium phosphate buffer at $\mathrm{pH} 6.5)$. The material was ground, filtered on gauze and centrifuged at $17,000 \mathrm{~g}$ for $30 \mathrm{~min}$ at $4{ }^{\circ} \mathrm{C}$ (Lagrimini et al., 1997).

In relation to the enzymatic activity of POD, $100 \mathrm{iL}$ of the enzyme extract was added to the reaction medium containing $0.5 \mathrm{~mL}$ of guaiacol $(1.7 \%), 1.5 \mathrm{~mL}$ of $0.1 \mathrm{~mol} \mathrm{~L}$ ${ }^{1}$ potassium phosphate buffer $(\mathrm{pH} 7.0)$ and $0.5 \mathrm{~mL}$ of hydrogen peroxide $(1.8 \%)$. Reading was performed in a spectrophotometer at $470 \mu \mathrm{m}$ and the data expressed in units of absorbance (UA) $\mathrm{min}^{-1} \mathrm{mg}^{-1}$ protein (Lagrimini et al., 1997).

Regarding enzymatic activity of PPO, the reaction medium was composed of $100 \mu \mathrm{L}$ enzyme extract, $1.5 \mathrm{~mL}$ of $0.1 \mathrm{~mol} \mathrm{~L}^{-1}$ potassium phosphate buffer $(\mathrm{pH} 7.0), 0.5 \mathrm{~mL}$ catechol and $0.9 \mathrm{~mL}$ of distilled water. The reading was performed at $420 \mathrm{ìm}$ and expressed in UA $\min ^{-1} \mathrm{mg}^{-1}$ protein (Kavrayan \& Aydemir, 2001).

Total protein was determined by the method of Bradford (1976) using bovine serum albumin (BSA) as standard.

The experiment was carried out in a completely randomized design, in split-plots, where the plots were the temperatures and in the subplots, the storage times. For the evaluations of TSS, RS, NRS, post-fry color and sprouting. Six replicates were used and for POD and PPO used 5 replicates, each replicate consisting of 2 tubers. The data were analyzed through analysis of variance and regression by using the statistical software SAEG 9.1 System of Statistical Analysis and Genetics (SAEG, 2007). The results of TSS and RS were expressed by the surface response method.

\section{RESULTS AND DISCUSSION}

The temperatures of 4 and $5{ }^{\circ} \mathrm{C}$ delayed the onset of sprouting, which started at 150 days. For temperatures of 6 and $8{ }^{\circ} \mathrm{C}$, sprouting occurred at 90 and 60 days of storage, respectively (Figure 1). Bisognin et al. (2008) observed that the rise in storage temperature accelerated the sprouting of the tubers and increased both the percentage of sprouted tubers and the number of sprouts per tubers.

The dormancy period is longer in tubers stored at low temperature, as there is a less use of the reserves necessary for bud sprouting (Bisognin \& Streck, 2009), conserving the potatoes for a longer period. Hence, the lower 
temperatures tend to delay the appearance of the sprouts. On the other hand, this temperature range favors the hydrolysis or degradation of the starch, and consequently, the accumulation of RS, which causes darkening of the sticks after frying.

High storage temperatures are associated with the promotion in the advancement of the physiological age of the tubers as the higher the temperature, the faster the aging process (Pavlista, 2004) and, consequently, the onset of sprouting. During bud growth, there is an increase in respiration to supply energy needs, promoting the degradation of the reserve substances, translocation of carbohydrates, loss of water by transpiration and consequently loss of fresh mass of tubers (Bisognin et al., 2008).

Regardless of temperature, TSS increased over the storage time (Figure 2A). The accumulation of TSS started at 30 days in the tubers at 4 and $5{ }^{\circ} \mathrm{C}$. In addition, in the tubers at 6 and $8{ }^{\circ} \mathrm{C}$, at 150 days, coinciding with the beginning of budding (Figure 2A and 1). The increase in $\mathrm{RS}$ contents over time occurred only at temperatures of 4 and $5^{\circ} \mathrm{C}$ (Figure 1B).

Tubers stored at 4 and $5^{\circ} \mathrm{C}$ had higher TSS and RS contents than those stored at 6 and $8{ }^{\circ} \mathrm{C}$ in all storage periods (Figure $2 \mathrm{~A}$ and $\mathrm{B}$ ). At 4 and $5^{\circ} \mathrm{C}$, values of TSS ranged from 0.6 to $1.2 \%$ over storage, while at temperatures of 6 and $8{ }^{\circ} \mathrm{C}$ remained between 0.2 and $0.8 \%$. For RSs, at $4{ }^{\circ} \mathrm{C}$, values above $0.4 \%$ were observed. While, at temperatures of 6 and $8{ }^{\circ} \mathrm{C}$ resulted in RS concentrations of less than $0.2 \%$ over the storage. The temperature that caused the lowest content of TSS and $\mathrm{RS}$ was $6.9^{\circ} \mathrm{C}$.

The RS contents suitable for processing should be below $0.3 \%$ (Zorzella et al., 2003). By the present work,

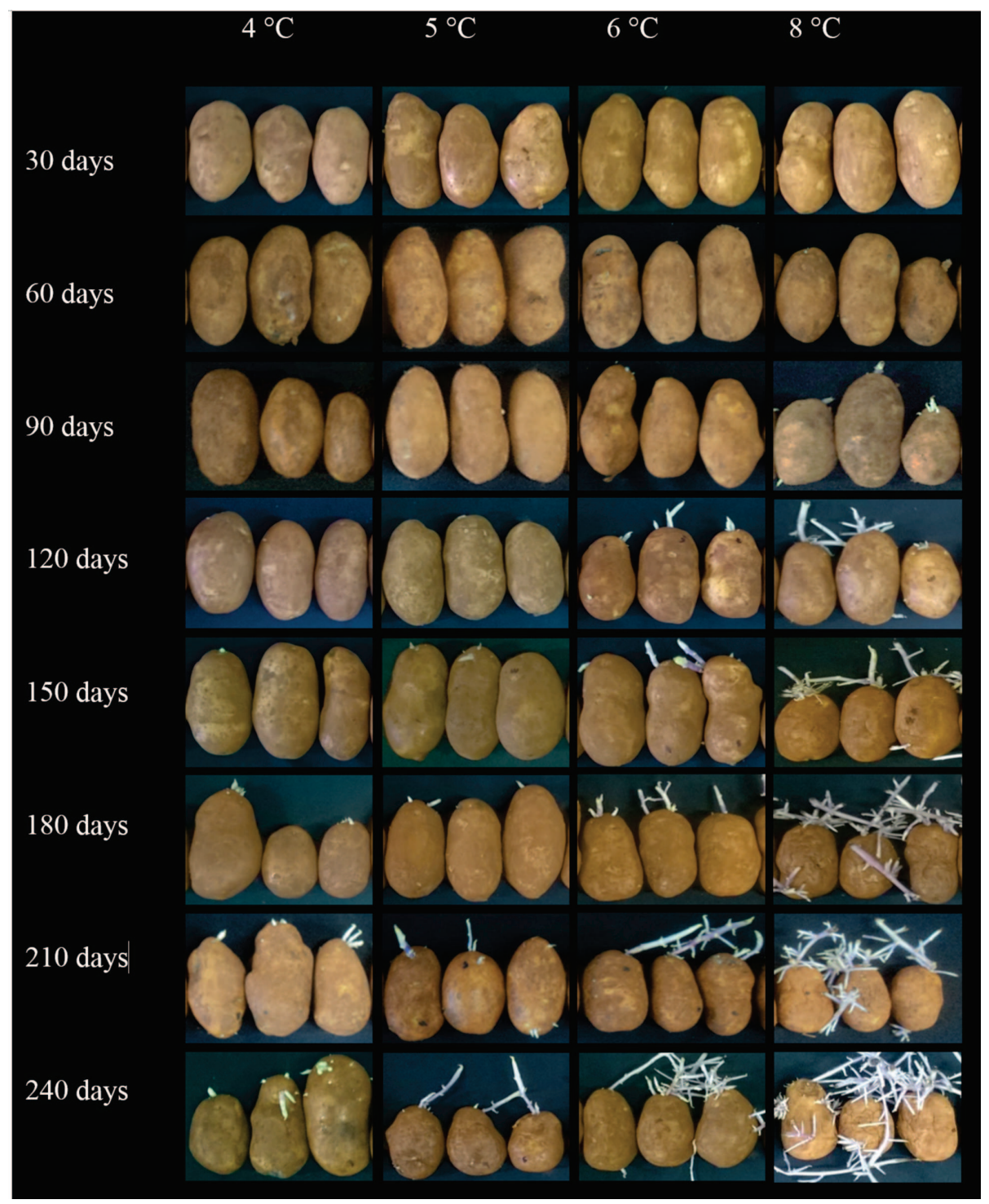

Figure 1: Sprouting onset of potato tubers (Solanum tuberosum L.) of the Markies cultivar stored at temperatures of 4, 5, 6 and 8 ${ }^{\circ} \mathrm{C}(\mathrm{RH} 90 \pm 2 \%)$ at $30,60,90,120,150,180,210$ and 240 days. 
the contents of RS found at temperatures of 6 and $8{ }^{\circ} \mathrm{C}$ are within the range of acceptance for the processing industry, but at storage temperatures of 4 and $5{ }^{\circ} \mathrm{C}$, these values were higher in the first 30 days of storage.

The accumulation of sucrose in tubers stored at low temperatures occurs for the purpose of cell protection (Pringle et al., 2009). At low temperatures, it occurs the activation of enzymes related to the degradation of starch, which is converted to sucrose (Braun et al., 2010). In addition, respiratory activity is reduced, resulting in the accumulation of TSS that is depends on temperature, and storage time (Braun et al., 2010) as observed in the present study.

The accumulation of TSS at low storage temperatures were observed in Pérola and Atlantic cultivars, between 0 and 10 days of storage, when the tubers were stored at 2 ${ }^{\circ} \mathrm{C}$, in comparison to those stored at $15{ }^{\circ} \mathrm{C}$ and at room conditions (Chapper et al., 2002). In the cultivars Pérola,

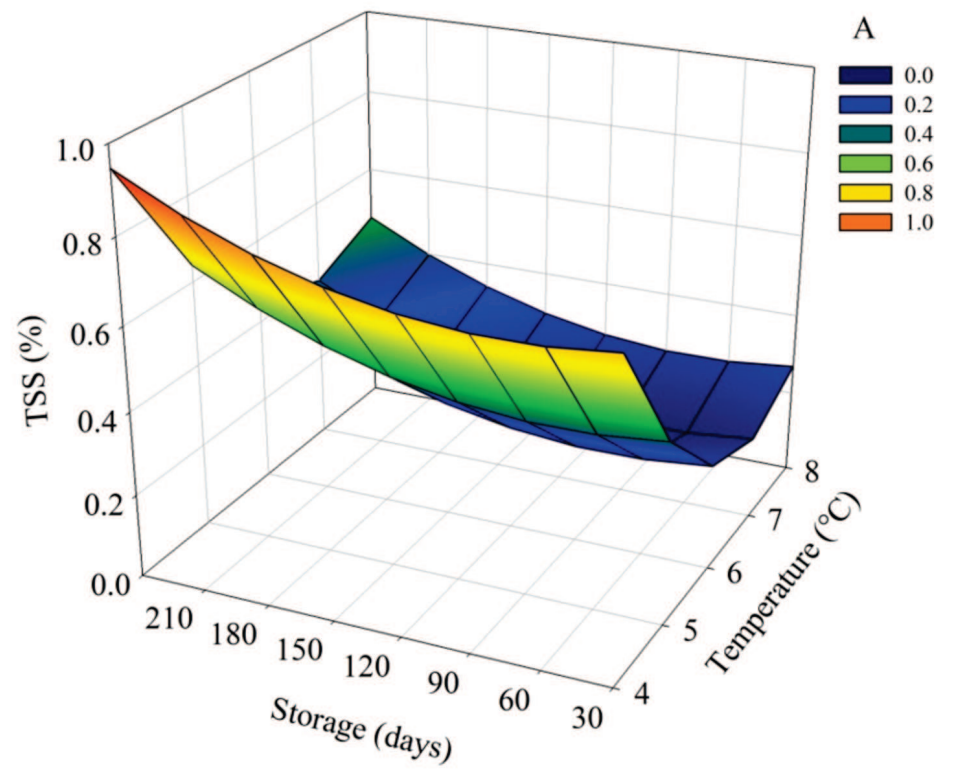

$\mathrm{y}=\underset{\wedge}{3.27}-\underset{\wedge}{0.0013 d}+0.0000084 d^{2}-0.8760 t+0.06317 t^{2} R^{2}=0.62$

$\mathrm{TSS} \min =[\mathrm{Ymin} ; 78.4 ; 6.9]$

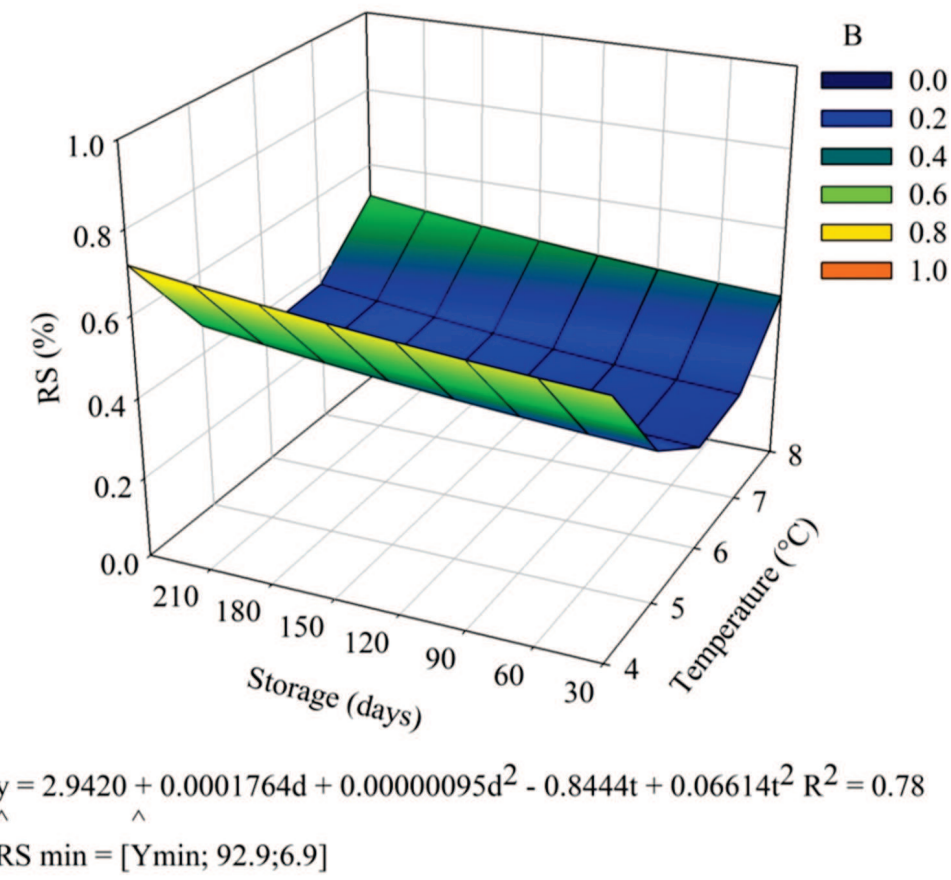

Figure 2: Total soluble sugar (TSS) and reducing sugars (RS) in potato tubers (Solanum tuberosum L.) of the Markies cultivar stored at temperatures of $4,5,6$ and $8{ }^{\circ} \mathrm{C}(\mathrm{RH} 90 \pm 2 \%)$ at 30, 60, 90, 120, 150, 180, 210 and 240 days.

Rev. Ceres, Viçosa, v. 68, n.2, p. 089-095, mar/apr, 2021 
Atlantic and Asterix, an increase in TSS and RS was observed when stored at $4{ }^{\circ} \mathrm{C}$ at 30 days of storage (Bacarin et al., 2005), causing a rapid loss in the quality (Zommick et al., 2014).

Despite the correlation between the post-fry color of the sticks and the contents of RS (Feltran et al., 2004), which are highly influenced by the storage conditions (Pastorini et al., 2003), only the content of RS is not sufficient to distinguish cultivars as to suitability for industrial processing. The evaluation of the color after the frying allows a more accurate conclusion, since the color is considered one of the most important parameters in the definition of the quality of the french fries, influencing the preference of the consumers, where the excessive darkening indicates low quality of the product (Pedreschi et al., 2007; Pastorini et al., 2003).

The color of the fried sticks prior to refrigerated storage indicates that $\mathrm{cv}$. Markies was within the color classification standards required for the processing industry (Figure 3). This result is in agreement with
Chapper et al. (2002), Bacarin et al. (2005) who state that tubers maintained at room temperature do not show significant changes in coloration.

The storage at $4{ }^{\circ} \mathrm{C}$ caused darker coloring after frying in relation to the other temperatures (Figure 3). This is in agreement with the RS data, since the temperature of $4{ }^{\circ} \mathrm{C}$ was also the one that caused the highest levels of RS (Figure 2B), demonstrating that there was a possible reaction between the carbonyl group of $\mathrm{RS}$ and the amino group of the amino acids over frying by the reaction of Maillard, which resulted in the darkening of the product.

The lower contents of RS (Figure 2B) coincided with the light color of the sticks after frying (Figure 3 ). Tubers at 6 and $8{ }^{\circ} \mathrm{C}$ were graded from day 2 until 240, allowing their use in industrial processing. However, at 120 days of storage at these temperatures, sprouting is already at an advanced stage of development at $8{ }^{\circ} \mathrm{C}$ (Figure 1), which represents an obstacle to the processing industry due to the problems caused by the sprouts inside the storage chambers.

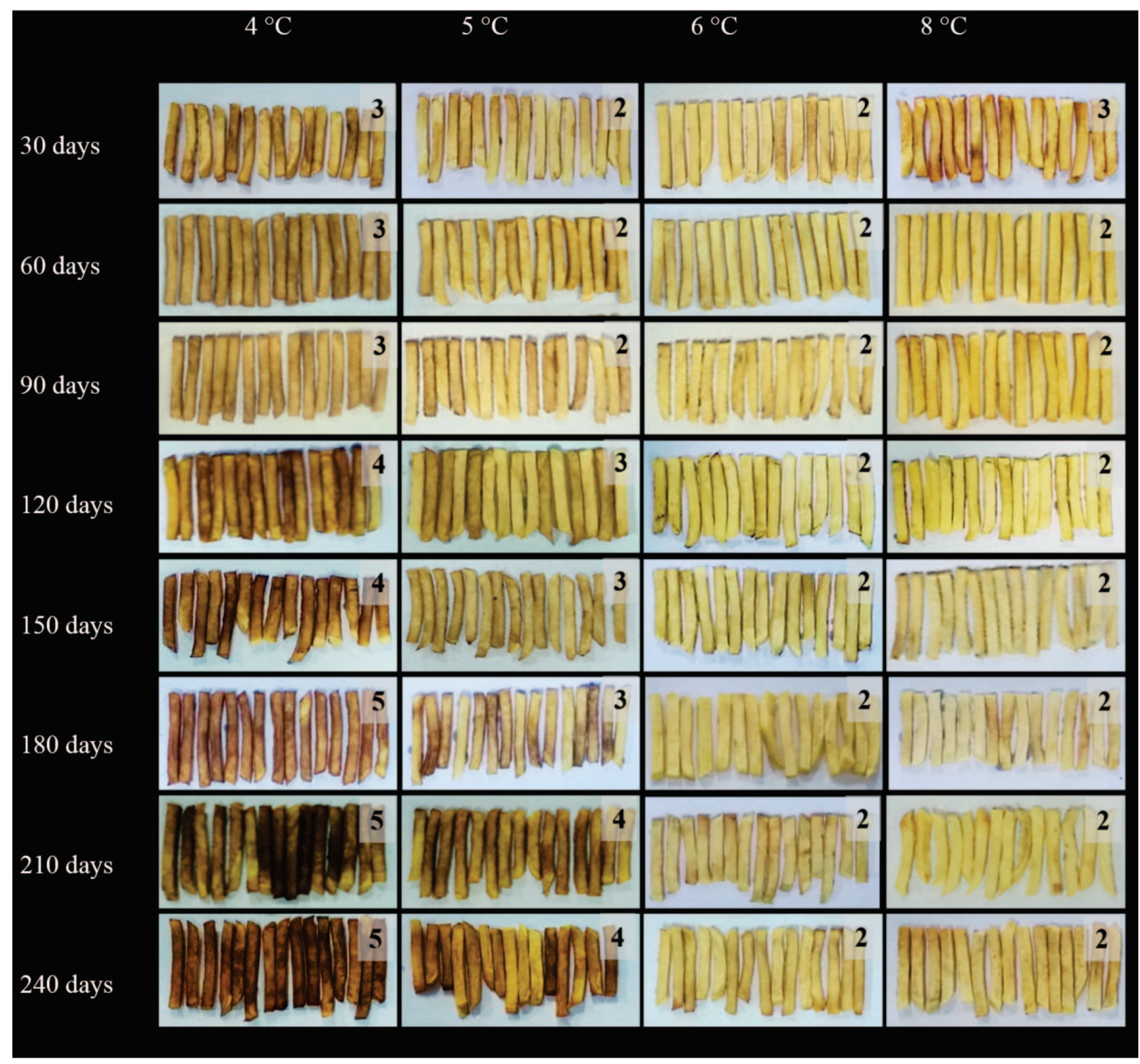

Figure 3: Post-frying coloring of potato sticks cv. Markies stored at 4, 5, 6 and $8{ }^{\circ} \mathrm{C}(\mathrm{RH} 90 \pm 2 \%)$ for 30, 60, 90, 120, 150, 180, 210 and 240 days. The numbers each photo represent the classification according to USDA and the fast food industry, ranging from 1 to 5 . 
At low temperature, the respiratory and sprouting rates are inhibited, resulting in lower consumption of reducing sugars accumulating in the tubers, resulting in dark color (Chapper et al., 2004; Knowles et al., 2009). These results are in agreement with Feltran et al. (2004), who, when determining the quality of processing of tubers of potato cultivars, affirmed that the contents of RS and/ or NRS are closely related to the quality of the product, with a negative effect on the coloration after frying.

Storage time and temperature did not affect the activity of POD and PPO enzymes. The mean values found in the study were 1.91 and $1.42 \mathrm{AU} \mathrm{min}^{-1} \mathrm{mg}^{-1}$ protein for POD and PPO, respectively. The low enzymatic activity did not result in darkening after the sticks were cut. These enzymes use phenolic compounds as substrates and cause undesirable changes in the color, taste and aroma of the vegetables (Valderrama et al., 2001). The darkening reactions are dependent on the degree of interaction between enzyme/substrate and the integrity of the membrane separating them. According to these authors, the integrity of the cell membranes deteriorates over damages or during the storage, with a variation in the content of the enzyme between species and cultivars. According to Zorzella et al. (2003) the change in color, taste and bitter taste of potato chips from different potato genotypes were attributed to POD and PPO activity. However, for the Markies cultivar, the temperatures and storage time used in the duty did not influence the enzymatic activity of POD and PPO.

\section{CONCLUSION}

The ideal temperature is essential to maintain the quality of the stored tubers. The Markies cultivar should be stored at $6^{\circ} \mathrm{C}$ for 240 days. In this condition, this cultivar has characteristics that are required by the processing industry. At lower temperatures there is an induction of the accumulation of reducing sugars, causing tubers with improper post-frying color. At higher temperatures, germination is promoted, representing an obstacle to the processing industry due to the problems caused by sprouts inside the chambers.

\section{ACKNOWLEDGEMENTS, FINANCIAL SUPPORT AND FULL DISCLOSURE}

There is no conflict of interest or funding for research and publication of the manuscript.

\section{REFERENCES}

Araújo JMA (2008) Química de Alimentos: teoria e prática. $4^{\text {th }}$ ed Viçosa, Editora UFV. 596p.

Bacarin MA, Ferreira LS, Deuner S, Bervald CMP, Zanatta ER \& Lopes NF (2005) Carboidratos não estruturais em tubérculos de batata recondicionados após o armazenamento sob diferentes temperaturas. Horticultura Brasileira, 23:799-804.
Bisognin DA, Freitas AT, Brackmann A, Andriolo JL, Pereira EIP, Muller DR \& Bandinelli MG (2008) Envelhecimento fisiológico de tubérculos de batata produzidos durante o outono e a primavera e armazenados em diferentes temperaturas. Bragantia, 67:59-65.

Bisognin DA \& Streck NA (2009) Desenvolvimento e manejo das plantas para a alta produtividade e qualidade da batata. Itapetininga, Associação Brasileira de Batata. 32p.

Bradford MM (1976) A rapid and sensitive method for the quantification of microgram quantities of protein utilizing the principle of protein-dye biding. Analytical Biochemistry, 72:248-254.

Braun H, Fontes PCR, Finger FL, Busato C \& Cecon PR (2010) Carboidratos e matéria seca de tubérculos de cultivares de batata influenciados por doses de nitrogênio. Ciência e Agrotecnologia, 34:285-293

Chapper M, Bacarin MA, Pereira AS \& Terrible LC (2002) Carboidratos não estruturais em tubérculos de dois genótipos de batata armazenados em duas temperaturas. Horticultura Brasileira, 20:348-355.

Chapper M, Loureiro ME, Mosquim PR, Araújo WL, Pereira AS, Finger FL \& Simões AN (2004) Mudanças metabólicas após recondicionamento a $15{ }^{\circ} \mathrm{C}$ de tubérculos de batata armazenados a baixa temperatura. Horticultura Brasileira, 22:597-601.

Dubois M, Gilles KA, Hamilton JK, Rebers PA \& Smith F (1956) Colorimetric method for determination of sugars and related substances. Analytical Chemistry, 28:350-356.

Feltran JC, Lemos LB \& Vieites RL (2004) Technological quality and utilization of potato tubers. Scientia Agricola, 61:598-603.

Gonçalves C, Rodriguez-Jasso RM, Gomes N, Teixeira JÁ \& Belo I (2010) Adaptation of dinitrosalicylic acid method to microtiter plates. Analytical Methods, 2:2046-2048.

Kavrayan D \& Aydemir T (2001) Partial purification and characterization of polyphenoloxidase from peppermint (Mentha piperita). Food Chemistry, 74:146-154.

Khanal B \& Uprety D (2014) Effects of storage temperature on post-harvest of potato. International Journal of Research, 1:903-909.

Knowles NR, Driskill EPJ \& Knowles LO (2009) Sweeting responses of potato tubers of different maturity to conventional and nonconventional storage temperature regimes. Postharvest Biology and Technology, 52:49-61.

Lagrimini LM, Gingas V, Finger FL, Rothstein S \& Liu TTY (1997) Characterization of antisense transformed plants deficient in the tobacco anionic peroxidase. Plant Physiology, 114:1187-1196.

Pastorini LH, Bacarin MA, Trevizol FC, Bervald CMP \& Fernandes HSF (2003) Produção e teor de carboidratos não estruturais em tubérculos de batata obtidos em duas épocas de plantio. Horticultura Brasileira, 21:660-665.

Pavlista AD (2004) Physilogical aging of seed tubers. Nebraska Potato Eyes, 16:2-3.

Pedreschi F, Leon J, Mery D, Moyano P, Pedreschi R, Kaack K \& Granby K (2007) Color development and acrylamide content of pre-dried potato chips. Journal of Food Engineering, 79:786793.

Pereira AS \& Suinaga FA (2015) Introdução e importância econômica. Available at: <https://www.infoteca.cnptia.embrapa.br/ infoteca/bitstream/doc/1028425/1/SistemadeProducaodaBatata.pdf $>$. Accessed on: October $24^{\text {th }}, 2017$.

Pringle R, Bishop C \& Clayton R (2009) Physiology. In: Potatoes Postharvest. Writtle College, The British Potato Council. 448p. 
Ribeiro JDR, Ribeiro GHMR \& Pinto CABP (2012) Evolução e desafios da bataticultura em Minas Gerais. Informe Agropecuário, $33: 7-13$.

Universidade Federal de Viçosa (2007) SAEG: Sistema para Análises Estatísticas e Genéticas. Versão 9.1. Viçosa, Fundação Arthur Bernardes. CD-ROM.

Thompson \& Morgan (2015) Potato 'Markies' (Early Maincrop) Solanum tuberosum. Available at: <http://www.thompsonmorgan.com/vegetables/potatoes/maincrop/potato-markies/ t17927TM\#additional-links>. Accessed on: August 9 ${ }^{\text {th }}, 2015$.

USDA (1967) United States Standards for Grades of Frozen French Fried Potatoes. Washington, USDA. 16p.
Valderrama P, Marangoni F \& Clemente E (2001) Efeito do tratamento térmico sobre a atividade de peroxidase (POD) e polifenoloxidase (PPO) em maçã (Mallus comunis). Ciência e Tecnologia de Alimentos, 21:321-325.

Zommick DH, Knowles LO \& Pavek MJ (2014) In-season heat stress compromises postharvest quality and low-temperature sweeting resistance in potato (Solanum tuberosum L.). Planta, 239:1243-1263.

Zorzella, CA, Vendruscolo JL \& Treptow RO (2003) Qualidade sensorial de "chips" de diferentes genótipos de batata (Solanum tuberosum L.), cultivos de primavera e outono no Rio Grande do Sul. Revista Brasileira de Agrociência, 9:57-63. 